ISSN 0103-5150

Fisioter. Mov., Curitiba, v. 28, n. 4, p. 657-665, Oct./Dec. 2015

Licenciado sob uma Licença Creative Commons

DOI: http://dx.doi.org.10.1590/0103-5150.028.004.A002

(c) (

\title{
Pelvic floor muscle strength and sexual function in women
}

\author{
Força muscular do assoalho pélvico e função sexual em mulheres
}

\author{
Cinara Sacomori, Janeisa Franck Virtuoso, Ana Paula Kruger, Fernando Luiz Cardoso*
}

Universidade do Estado de Santa Catarina (UDESC), Florianópolis, SC, Brazil

\begin{abstract}
Introduction: Pelvic floor (PF) muscles react to sexual stimuli with increased local blood circulation and involuntary contractions during orgasm. The training of the PF musculature helps in the improvement of the female sexual function. Objective: To verify the association between PF muscle strength and sexual function in women, controlling age and parity. Method: Cross-sectional study based on associations. The study included women who attended a reference center in Florianópolis, Santa Catarina, for a uterine cancer smear test. The Functional Evaluation of the Pelvic Floor and the Female Sexual Function Index questionnaire were used. Statistical procedures included Mann-Whitney U tests, Spearman correlation and Poisson Regression Analysis, with $\mathrm{p}<.05$. Results: The mean age of the women $(\mathrm{n}=177)$ was 39.05 years $(\mathrm{SD}=13.3)$. Regarding PF function, $53.7 \%$ of participants presented weak or not palpable PF muscle function. Women with "good" muscle function (able to maintain contraction under examiner's resistance) had significantly better indexes of sexual desire, excitement, lubrication and orgasm than women with weak/poor function. We identified that $52.5 \%$ of the women presented sexual dysfunction. Women with "poor" PF function and aged over 50 years had, respectively, 1.36 (CI95\% 1.01 - 1.82) and 1.77 (CI95\% 1.41 - 2.23) higher prevalence of sexual
\end{abstract}

* CS: PhD, e-mail: csacomori@yahoo.com.br JFV: PhD, e-mail: janeisav@yahoo.com.br APK: MSc, e-mail: ana.pkruger@hotmail.com

FLC: PhD, e-mail: fernando.cardoso@udesc.br 
dysfunction than women with "good" PF function. Conclusions: Adult women with better PF muscle function also presented better sexual function.

Keywords: Sexual dysfunction. Pelvic floor. Muscle strength. Physical therapy. Sexuality.

\section{Resumo}

Introdução: Os músculos do assoalho pélvico (MAP) respondem aos estímulos sexuais, com aumento da circulação sanguínea local e contrações involuntárias durante o orgasmo. O treinamento dessa musculatura promove melhora da função sexual feminina. Objetivo: Verificar a associação entre a força muscular dos MAP e função sexual em mulheres, controlando idade e paridade. Método: Estudo transversal de associação. Foram avaliadas mulheres atendidas num centro de referência para rastreamento do câncer de colo uterino de Florianópolis/SC. Utilizou-se a Avaliação Funcional do Assoalho Pélvico e o questionário Female Sexual Function Index. Os recursos estatísticos incluíram os testes U de Mann Whitney, correlação de Spearman e Regressão de Poisson, $p<0,05$. Resultados: A média de idade das participantes ( $n=177)$ foi 39,05 anos ( $D P=$ $\pm 13,3)$. Com relação à função dos MAP, 53,7\% apresentaram contração não palpável ou débil. As mulheres com função muscular de boa qualidade (que vencia a resistência manual feita pelo avaliador) tiveram significativamente maior desejo, excitação, lubrificação e orgasmo do que aquelas com função débil/ruim. Identificou-se que 52,5\% das mulheres tinham disfunção sexual. Mulheres com função dos MAP "ruim" e idade superior a 50 anos apresentaram, respectivamente, 1.36 (IC95\% 1,01 - 1,82) e 1.77 (IC95\% 1,41 - 2,23) maior prevalência de disfunção sexual que as mulheres com "boa" função muscular. Conclusões: Mulheres adultas com melhor função dos MAP também apresentam melhor função sexual.

Palavras-chave: Disfunção sexual. Diafragma da pelve. Força muscular. Fisioterapia. Sexualidade.

\section{Introduction}

According to Bergeron, Binik, Khalifé \& Cohen (1) technical literature has shown the participation of physical therapists in multidisciplinary teams to treat sexual dysfunctions in women. The physical therapy approach in human sexuality consists of guidelines on pelvic anatomy and sexual disorders, behavioral education, body awareness, vaginal desensitization, perineal massage, and reeducation of the pelvic floor (PF) muscles $(2,3)$.

Sexual health is an important aspect in women's quality of life. The purpose of the female sexual response, in biological terms, is to facilitate penis penetration and, at the same time, provide erotic sensations ensuring good reproductive fitness (4). Sexual dysfunction involves physical, social and psychological dimensions, affecting any phase of the sexual functioning: desire (libido), excitement, lubrication, orgasm, satisfaction, and pain (5).

The first systematic studies on the human sexual response cycle were performed by Masters and Johnson (6), who established a laboratory in which the anatomical and physiological correlates of sexual excitement and climax were documented. These authors have produced the most widely accepted model of sexual response structured in four stages: excitement, plateau, orgasm, and resolution (6). Kaplan (7) extended and modified Masters and Johnson's work by proposing a new phasic formulation of sexual response with the introduction of the desire phase and improvement of the plateau and resolution phases. Sexual response was divided as desire, excitement, and orgasm (8). Since then, the term "sexual function" is used. It includes, in addition to the previously mentioned aspects, dyspareunia and sexual satisfaction (9).

The pelvic floor (PF) muscles react to sexual stimuli with increased local blood circulation and involuntary contractions during orgasm (10). Training the pelvic floor muscles helps improve female sexual function, in all its domains (11-16). According to Kegel (17), disuse, weakness, and hypotonicity of PF muscles contribute to orgasmic failure. However, it is not clear which aspects of these muscles, such as increased strength, endurance, or other aspects of 
motor control, would be more involved in improving sexual function.

Thus, little is known about the relationship between PF and sexual function among typical women because studies are commonly developed with women who already have some pelvic floor dysfunction (18-20). A population-based study showed that satisfaction and sexual activity were independent of the presence or absence of pelvic floor dysfunction when examined in a multivariate model (21). However, this study did not measure aspects such as muscle strength and endurance in a more direct way. Paciornik (22) emphasizes the importance of assessing the level of perineal strength both for research and for clinical purposes.

Given this context, the aim of this study was to verify the association between PF muscle strength and sexual function in women, controlling age and parity.

\section{Method}

Type of study

A cross-sectional study was developed, since the objective was to verify the association between PF muscle strength and sexual function in adult women.

\section{Population and sample}

The study population consisted of approximately 2,500 women attending a reference center in Florianópolis, Santa Catarina, for uterine cancer smear tests. In this center, women are interviewed and undergo cytopathological exams, without prior appointment. The sample was selected intentionally. Data were collected on Thursdays, in the afternoon, between the months of November 2010 and June 2011 , subject to availability of the place. Women attended the center without prior appointment, and there was up to 12 vacancies per period. They were invited to participate in the study prior to the cancer smear tests. Pregnant women, women under the age of 18 years and sexually inactive women were not included in the study. Through volunteer work, 177 women aged between 18 and 75 years were recruited during this period.
Instruments

The variables listed to characterize the sampling in this study were age, education, marital status and presence of diseases. The number of pregnancies was also collected and women were classified as nulliparous or multiparous.

To identify the body mass index (BMI), we measured body weight through an Inner Scan digital scale model BC - 533/Brand Tanita and height through $217 \mathrm{~cm}$ WCS stadiometer brand CARDIOMED with platform. Body mass index is obtained by dividing body weight in kilograms by height in square meters $\left(\mathrm{kg} / \mathrm{m}^{2}\right)$.

To measure the muscle function of the pelvic floor, we used the Functional Evaluation of the Pelvic Floor (FEPF) proposed by Ortiz et al. (23), which measures the presence and intensity of voluntary muscle contraction of these muscles. Muscle function was graded from zero (no objective perineal function, not even on palpation) to four (objective perineal function present and opposing resistance maintained for more than 5 seconds).

For this evaluation, the participant was placed in supine position on a stretcher, with the head resting on a pillow, hips flexed and slightly abducted and knees flexed and supported on a wedge of about 20 $\mathrm{cm}$. The test was performed by means of vaginal palpation, wherein the evaluator used disposable gloves.

For data analysis, muscle function of the pelvic floor was treated in a numerical and categorical manner, and the classification used was: "poor" muscle function (equivalent to FEPF between zero and two, when contraction is weak or not palpable) and "good" muscle function (equivalent to FEPF three and four, when there is ability to resist the opposition made by the examiner in the lateral-inferior direction).

The sexual function of the participants was measured using the Female Sexual Function Index (FSFI) questionnaire applied as an interview, which was developed and validated in the United States (24) and translated into Portuguese (25). The questionnaire consists of 19 questions, all multiple choice, grouped into six areas: desire, excitement, lubrication, orgasm, satisfaction and pain. Each answer is assigned a value from 0 to 5 . A mathematical calculation is performed to obtain a final index, the FSFI score. Results vary from 2 to 36, and the lower the score obtained, the worse the sexual function. 
For data analysis, sexual function was evaluated numerically and categorically, and the classification used was given by the cutoff point 26 as there is no sexual dysfunction rank values from the FSFI score for the Brazilian population and it is an intermediate value between the cutoff points for sexual dysfunction obtained in the US and in Turkey (24-26). Sexual function was considered as "good/no dysfunction" to values above this cutoff point and as "dysfunction" to values below it.

\section{Data collection}

Women were invited to participate in the study before undergoing the smear test, and the study purpose and confidentiality of identification were previously explained.

Data were collected by female physical therapists and female physical therapy students who were previously trained. First, they collected the sample identification data, followed by the application of the Female Sexual Function Index (FSFI). Finally, the PF muscles were evaluated.

\section{Data analysis}

Data were organized and analyzed using the SPSS (Statistical Package for the Social Sciences) statistical program - version 17.0 for Windows. Descriptive statistical analysis was performed by means of simple and relative frequency, mean, median and standard deviation.

For inferential analysis, we used the MannWhitney U test and Spearman correlation, because the dependent variable "sexual function" did not follow the normality criteria. A Poisson regression analysis with robust estimation and interaction model was performed using the backward elimination process, where the variables without statistical significance were eliminated at different phases. The prevalence ratio was calculated considering sexual function (good function/dysfunction) as dependent variable, and function of the pelvic floor (good/poor), age (up to 50 years/more than 50 years), and parity (nulliparous/multiparous) as independent variables. Significance was set at $5 \%$.
Ethical aspects

This study was developed in compliance with the standards required by resolution no. 196/96 of the National Health Council of Brazil and approved by the Human Research Ethics Committee of the State University of Santa Catarina (UDESC) under protocol number $156 / 2010$. Prior to implementation of the instruments, the women who agreed to participate in the study signed a consent form.

\section{Results}

A total of 177 women with a mean age of 39.05 years (SD $= \pm 13.3$ ) participated in this study, most of whom were married (64.4\%) and had completed high school education (46.9\%), as noted in Table 1. Regarding the presence of self-reported diseases, $14.7 \%$ suffered from depression and $2.3 \%$ had diabetes. Twenty-five women $(14.1 \%)$ were not sexually active (with sexual intercourse) during the study period - the last four weeks prior to the interview.

Regarding the muscle function of the pelvic floor, $53.7 \%(\mathrm{n}=95)$ of the women had "poor" classification, whereas $46.3 \%(n=82)$ were classified as "good". More specifically, only 4\% ( $\mathrm{n}=7)$ was unable to contract the PF muscles (level 0), 26\% ( $n=46)$ had no objective perineal function, with contraction noticed only on palpation (level 1), 23.7\% ( $\mathrm{n}=42$ ) had poor objective perineal function with contraction noticed on palpation (level 2), $21.5 \%(n=38)$ had objective function and opposing resistance not maintained for more than five seconds (level 3) and $24.9 \%(n=44)$ had objective function and opposing resistance maintained for more than five seconds (level 4).

Table 2 presents the comparison between domains and the FSFI total score, according to the functional classification of the PF muscles. Note that women with "good" muscle function had significantly better sexual function than those with "poor" function. Therefore, women with "good" muscle function had more desire, excitement, lubrication and orgasm than those with "poor" muscle function. Concerning pain during sexual intercourse, there was no relevant difference among groups. 
Table 1 - Characteristics of the study participants regarding sociodemographic variables and diseases depending on the BMI classification

\begin{tabular}{|c|c|c|c|c|c|c|}
\hline & \multicolumn{2}{|c|}{$\begin{array}{c}\text { All } \\
(n=177)\end{array}$} & \multicolumn{2}{|c|}{$\begin{array}{l}\text { Poor muscle }{ }^{\#} \\
(\mathrm{n}=95)\end{array}$} & \multicolumn{2}{|c|}{$\begin{array}{l}\text { Good muscle function } \\
\qquad(\mathrm{n}=82)\end{array}$} \\
\hline & $\mathrm{n}$ & $\%$ & $\mathrm{n}$ & $\%$ & $\mathrm{n}$ & $\%$ \\
\hline \multicolumn{7}{|l|}{ Education } \\
\hline Illiterate & 3 & 1.7 & 1 & 1.1 & 2 & 2.4 \\
\hline Elementary school & 46 & 25.9 & 34 & 35.8 & 12 & 14.6 \\
\hline High school & 83 & 46.9 & 44 & 46.3 & 39 & 47.6 \\
\hline Undergraduate & 45 & 25.4 & 16 & 16.9 & 29 & 35.4 \\
\hline \multicolumn{7}{|l|}{ Marital status } \\
\hline Married & 114 & 64.4 & 68 & 71.6 & 46 & 56.1 \\
\hline Single & 43 & 24.3 & 12 & 12.6 & 31 & 37.8 \\
\hline Separated/divorced & 13 & 7.3 & 9 & 9.5 & 4 & 4.9 \\
\hline Widowed & 7 & 4 & 6 & 6.3 & 1 & 1.2 \\
\hline \multicolumn{7}{|l|}{ Diseases } \\
\hline Diabetes & 4 & 2.3 & 4 & 4.2 & 0 & 0 \\
\hline Depression & 26 & 14.7 & 20 & 21.1 & 6 & 7.3 \\
\hline
\end{tabular}

Note: * Equivalent to not palpable or weak contraction according to Ortiz's classification scale; ^ equivalent to ability to withstand the opposition strength made by the examiner in the lateral-inferior direction according to Ortiz's classification scale.

Table 2 - Comparison of sexual function among women with poor and good PF muscle function

(to be continued)

\begin{tabular}{|c|c|c|c|c|c|c|c|}
\hline & \multicolumn{3}{|c|}{$\begin{array}{l}\text { Poor PF muscle function }{ }^{\#} \\
\qquad(\mathrm{n}=95)\end{array}$} & \multicolumn{3}{|c|}{$\begin{array}{l}\text { Good PF muscle function } \\
\qquad(\mathrm{n}=82)\end{array}$} & \multirow[t]{2}{*}{$\begin{array}{l}\text { Mann-Whitney } \\
\text { U test }\end{array}$} \\
\hline & Mean & SD & Md & Mean & SD & Md & \\
\hline \multirow[t]{2}{*}{$\mathrm{FSF}^{*}$} & 20.7 & 10.4 & 24.3 & 25.3 & 7.5 & 27.6 & $U=2888.5$ \\
\hline & & & & & & & $p=.003$ \\
\hline \multirow[t]{2}{*}{ Desire } & 3.1 & 1.4 & 3.0 & 3.6 & 1.1 & 3.6 & $U=2949$ \\
\hline & & & & & & & $p=.005$ \\
\hline \multirow[t]{2}{*}{ Excitement } & 3.0 & 1.8 & 3.6 & 3.9 & 1.5 & 4.5 & $U=2911$ \\
\hline & & & & & & & $p=.004$ \\
\hline \multirow[t]{2}{*}{ Lubrication } & 3.6 & 2.3 & 4.5 & 4.3 & 1.7 & 4.8 & $U=3332.5$ \\
\hline & & & & & & & $p=.095$ \\
\hline
\end{tabular}


Table 2 - Comparison of sexual function among women with poor and good PF muscle function

(conclusion)

\begin{tabular}{|c|c|c|c|c|c|c|c|}
\hline & \multicolumn{3}{|c|}{$\begin{array}{l}\text { Poor PF muscle function }{ }^{\#} \\
\qquad(\mathrm{n}=95)\end{array}$} & \multicolumn{3}{|c|}{$\begin{array}{l}\text { Good PF muscle function } \\
\qquad(\mathrm{n}=82)\end{array}$} & \multirow[t]{2}{*}{$\begin{array}{l}\text { Mann-Whitney } \\
\text { U test }\end{array}$} \\
\hline & Mean & SD & Md & Mean & SD & $\mathrm{Md}$ & \\
\hline \multirow[t]{2}{*}{ Orgasm } & 3.4 & 2.1 & 4.0 & 4.4 & 1.6 & 4.8 & $U=2898.5$ \\
\hline & & & & & & & $p=.003$ \\
\hline \multirow[t]{2}{*}{ Satisfaction } & 3.6 & 2.0 & 4.0 & 4.7 & 1.6 & 5.2 & $U=2713.5$ \\
\hline & & & & & & & $p=.001$ \\
\hline \multirow[t]{2}{*}{ Pain } & 3.9 & 2.3 & 4.8 & 4.5 & 1.9 & 5.4 & $U=3418$ \\
\hline & & & & & & & $p=.145$ \\
\hline \multirow[t]{2}{*}{ Age } & 41.2 & 12.7 & 40 & 36.5 & 13.7 & 33 & $U=2991$ \\
\hline & & & & & & & $p=.008$ \\
\hline \multirow[t]{2}{*}{$\begin{array}{l}\text { No. of } \\
\text { pregnancies }\end{array}$} & 2.3 & 2.0 & 2.0 & 1.7 & 2.1 & 1 & $U=2916.5$ \\
\hline & & & & & & & $p=.003$ \\
\hline \multirow[t]{2}{*}{ BMI } & 26.1 & 5.7 & 25.3 & 24.5 & 3.7 & 23.8 & $U=3010.5$ \\
\hline & & & & & & & $p=.117$ \\
\hline
\end{tabular}

Note: * FSFI= Female Sexual Function Index; \# equivalent to not palpable or weak contraction according to Ortiz's classification scale; ^ equivalent to ability to withstand the opposition strength made by the examiner in the lateral-inferior direction according to Ortiz's classification scale.

In addition to sexual function, the age, number of pregnancies and BMI variables also differed between women with "good" and "poor" muscle function (Table 2). Women with "good" muscle function were younger, had fewer pregnancies and had a lower BMI.

Regarding the classification applied to sexual function, $47.5 \%$ had "good function", whereas $52.5 \%$ had sexual dysfunction. When applying Poisson's regression analysis to explain sexual function, we used the backward procedure, and the parity (nulliparous/ multiparous) variable was excluded from the model because it was not statistically significant. The final result indicated that women with "poor" pelvic floor muscle function showed a 1.36 higher prevalence of sexual dysfunction than those with "good" muscle function (Table 3). Furthermore, women aged above 50 years had a 1.77 higher prevalence of sexual dysfunction.
Table 3 - Association among sexual function, pelvic floor function and age

\begin{tabular}{llllc}
\hline $\begin{array}{c}\text { Variables } \\
\text { related }\end{array}$ & & $\begin{array}{c}\text { Prevalence } \\
\text { Ratio }\end{array}$ & Cl & P \\
\hline PF function & Good\# $^{\#}$ & 1 & $1.01-1.82$ & \\
& Poor $^{\wedge}$ & 1.36 & & \\
Age & $\begin{array}{l}\leq 50 \\
\text { years }\end{array}$ & 1 & & \\
& $>50$ & 1.77 & $1.41-2.23$ & \\
\hline & years & & & \\
\hline
\end{tabular}

Note: *Model suitable to data because Goodness-of-fit test was not significant $(p=0.637)$ and the Omnibus test was significant $(p=0.012) ;$; equivalent to not palpable or weak contraction according to Ortiz's classification scale; ^ equivalent to ability to withstand the opposition strength made by the examiner in the lateral-inferior direction according to Ortiz's classification scale. 


\section{Discussion}

This study presents relevant data in order to describe the association between PF muscles function and sexual function in women from general typical population. We found that women with weak contraction of pelvic floor muscles had a 1.36 higher probability of having sexual dysfunction. This finding suggests an association between a stronger pelvic floor musculature and better female sexual function, and it was already suggested in other studies (1116). A similar association was found in a study on pregnant women (27).

Women with better sexual function in this study had more desire, excitement, better lubrication, orgasm and less pain. This improved sexual function, according to Chambless, Sultan, Stern, O'Neill, Garrison, \& Jackson (11), occurs due to stronger muscles inserted in the cavernous body of the clitoris which, according to Shafik (15), may facilitate the sensorimotor reflex response (involuntary contraction of PF muscles during orgasm), improving pelvic blood flow, pelvic mobility and clitoral sensitivity, which are important aspects for excitement and orgasm $(28,29)$. On the other hand, a population-based study showed that satisfaction and sexual activity were independent of the presence or absence of pelvic floor dysfunction when examined in a multivariate model (21). This lack of association found in the previous study could be explained by the fact that the pattern of muscle contraction of the participants was not evaluated objectively, based only on self-assessment.

Human sexual function is very complex and it is divided into two basic principles of response, a reflex principle and a psychogenic principle (30). Technical literature has produced more evidence on the effects of pelvic floor strength on the reflex responses as has been previously mentioned, but there are few studies on the pelvic floor strength affecting psychogenic responses. Sacomori, Cardoso \& Vanderlinde (31) showed that a stronger pelvic floor was positively associated with different variables of body selfperception, for example, in finding their bodies are beautiful, sexy, finding that others consider them as sexy women, finding their bodies are proportional, besides knowing and touching their bodies in a more frequent basis.

Basson (32) built a new model of female sexual response that incorporates the importance of emotional intimacy, sexual stimulation and satisfaction with the relationship. This model claims that female sexual function is more complex and circular than male sexual function and sexual function is dramatically and significantly affected by many psychosocial variables (e.g. satisfaction with the relationship, self-image, previous negative sexual experiences). For Basson (32), women have many more reasons to engage in sexual activity in addition to sexual orientation and desire; most women in long-term relationships do not often think about sex or experience spontaneous desire for sexual activity. In the latter cases, the author suggests that the desire for increased emotional closeness and intimacy or readiness to talk of a partner may predispose a woman to sexual activity. From this point of sexual neutrality - where a woman is receptive to sex but does not initiate sexual activity - the desire for sex makes her sexually stimulable by means of talking, music, reading or watching erotic materials, or direct stimulation.

The Basson's model (32) explains that the purpose of sexual activity for women is not necessarily orgasm, but personal satisfaction that can be manifested as physical satisfaction (orgasm) and/ or emotional satisfaction - a sense of intimacy and connection with a partner, etc.

Cardoso, Savall, Sabbag, Mendes \& Beltrame (33) present the differences in terms of corporeality and sexuality between men and women. Participants reporting body satisfaction tend to be sexually satisfied. However, when biological sex is controlled this correlation is observed only among women. Men are more susceptible to having higher physical intimacy whereas women value more intimate caresses.

Finally, it still has to be defined if a better PF function would facilitate sexual function or vice versa. According to $\mathrm{B} \varnothing(34)$, there is a lack of randomized controlled tests investigating the role of PF muscles training in the treatment of sexual dysfunction. Since the pelvic floor strength had a positive influence on sexual function in this study, in typical women without any prior medical diagnosis, can be suggested that it may be more evident to women with different types of sexual dysfunction. For the next studies, aimed at a better understanding of the relationship between pelvic floor strength and female sexual function, the authors suggest an increased control of factors affecting the psychogenic responses of sexual function like self-image and body satisfaction. 


\section{Conclusion}

This study found that sexual dysfunction is associated with poor pelvic floor muscle strength (equivalent to not palpable or weak contraction) and age over 50 years. In addition, women with better muscle strength had more desire, excitement, lubrication, and orgasm than women who were not able to maintain the contraction against resistance.

These results confirm the clinical importance of PF muscle training to improve muscle contraction and, therefore, female sexual function. These conservative measures are even more important for women aged over 50 years.

This study had limitations such as having a crosssectional study design that does not allow understanding the causal relationships among variables and not having controlled the most psychogenic aspects that could interfere with sexual functioning. Among the strengths of the study, it is worth mentioning that it is one of the few studies to examine the association between sexual function and pelvic floor contractility in women without specific complaints. For future studies, it is suggested to use a design that allows for a better analysis on the influence of other physical and emotional variables on the occurrence of sexual dysfunctions. Furthermore, randomized clinical tests to identify efficient protocols, according to the level of PF muscle strength, are required to reduce prevalence rates of pelvic floor dysfunctions.

\section{References}

1. Bergeron S, Binik YM, Khalifé S, Cohen D. Dyspareunia: Sexual dysfunction or pain syndrome? J Nerv and Ment Dis. 1997;185(9):561-9.

2. Baracho E. Fisioterapia aplicada à obstetrícia, uroginecologia e aspectos de mastologia. 4 ed. Rio de Janeiro: Guanabara Koogan; 2007.

3. Etienne MA, Waitman MC. Disfunções sexuais femininas: a fisioterapia como recurso terapêutico. 1 ed. São Paulo: Livraria Médica Paulista Editora; 2006.

4. Revin R, Riley A. The physiology of human sexual function. Psychiatry. 2007;6(3):64-8.

5. Achtari C, Dwyer PL. Sexual function and pelvic floor disorders. Best practice \& research. Clinical obstetrics \& gynaecology. 2005 Dec;19(6):993-1008.
6. Master WH, Johnson VE. Human sexual response. Great Britain: Little Brown; 1966.

7. Kaplan HS. A nova terapia do sexo: tratamento dinâmico das disfunções sexuais. 1 ed. Rio de Janeiro: Nova Fronteira; 1977.

8. Mannocci JF. Disfunções sexuais: abordagem clínica e terapêutica. São Paulo: Fundo Editorial BYK; 1995.

9. Rosen R, Brown C, Heiman J, Leiblum S, Meston C, Shabsigh $\mathrm{R}$, et al. The female sexual function index (FSFI): a multidimensional self-report instrument for the assessment of female sexual function. J Sex Marital Ther. 2000;26(2):191-208.

10. Masters WH, Johnson VE, Kolodny RC. Human sexuality. 2nd ed. Toronto: Little, Brown and Company; 1985.

11. Chambless DL, Sultan FE, Stern TE, O'Neill C, Garrison S, Jackson A. Effect of pubococcygeal exercise on coital orgasm in women. J Consult Clin Psychol. 1984;52(1):114-8.

12. Beji NK, Yalcin O, Erkan HA. The effect of pelvic floor training on sexual function of treated patients. Int Urogynecol J Pelvic Floor Dysfunct 2003;14(4):234-8.

13. Grosse D, Sengler J. Reeducação perineal. 1 ed. São Paulo: Manole; 2002.

14. Piassarolli VP, Hardy E, Andrade NF, Ferreira NO, Osis MJD. Treinamento dos músculos do assoalho pélvico nas disfunções sexuais femininas. Rev Bras de Ginecol e Obstet. 2010;32(5):234-40.

15. Shafik A. The role of the levator ani muscle in evacuation, sexual performance, and pelvic floor disorders. Int Urogynecol J Pelvic Floor Dysfunct. 2000; 11(6): 361-76.

16. Zahariou AG, Karamouti MV, Papaioannou PD. Pelvic floor muscle training improves sexual function of women with stress urinary incontinence. Int Urogynecol J Pelvic Floor Dysfunct. 2008;19(3):401-6.

17. Kegel A. Sexual functions of the pubococcygeus muscle. West J. Surg Obstet Gynecol. 1952;60(10):521-4.

18. Schroder MA, Mell LKM, Hurteau JA, Collins YC, Rotmensch J, Waggoner SE, et al. Clitorial therapy device for treatment of sexual dysfunction in irradiated cervical cancer patients. Int J Radiat Oncol Biol Phys. 2005;1078-86. 
19. Weijmar Schultz WCMW, Van de Wiel BMV. Sexuality, intimacy, and gynecological cancer. J Sex Marital Ther. 2003; 29:121-8.

20. Denton AS, Maher EJ. Interventions for the physical aspects of sexual dysfunction in women following pelvic radiotherapy. Cochrane Database Syst Rev. 2003;(1):CD003750.

21. 21 Lukacz ES, Lawrence JM, Contreras R, et al. Parity, mode of delivery, and pelvic floor disorders. Obstet Gynecol. 2006 Jun; 107(6):1253-60.

22. Paciornik M. Aprenda a nascer e a viver com os índios: parto de cócoras, desempenho sexual e ginástica indiana. 1st ed. Rio de Janeiro: Rosa dos tempos; 1997.

23. Ortiz OC, Nuoez FC, Gutnisky R, Cortece G. Valoración dinâmica de la disfuncion perineal em la mujer. Propuesta de classificación. Obstet Ginec Lat Americ. 1994;52(1):92-8.

24. Wiegel M, Meston C, Rosen R. The female sexual function index (FSFI): cross-validation and development of clinical cutoff scores. J Sex Marital Ther. 2005;31(1):1-20.

25. Hentschel H, Alberton DL, Capp E, Goldim JR, Passos EP. Validação do female sexual function index (FSFI) para uso em língua portuguesa. Rev HCPA. 2007; 27(1):10-4.

26. Oksuz E, Malhan S. Reliability and validity of the female sexual function cross-validation and development of clinical cutoff scores. J Sex Marital Ther. 2005;31(3):1-20.

27. Franceschet J, Sacomori C, Cardoso FL. Strength of pelvic floor muscles and sexual function during pregnancy. Res Bras Fisioter. 2009;13(5):1-7.
28. Graber B, Kline-Graber G. Female orgasm: role of pubococcygeus muscle. J Clin Psychiatry. 1979;40(8): 348-51.

29. Ma Y, Qin H. Pelvic floor muscle exercises may improve female sexual function. Med Hypotheses. 2009;72(2):223.

30. Thomas Jefferson University Hospital. Spinal Cord Injury Manual. 2001;44p.

31. Sacomori C, Cardoso FL, Vanderlinde C. Pelvic floor muscle strength and body self-perception among Brazilian pregnant women. Physiotherapy. 2010; 96(4):337-43.

32. Basson R. Using a different model for female sexual response to address women's problematic low sexual desire. J Sex Marital Ther. 2001;27(5):395-403.

33. Cardoso FL, Savall AC, Sabbag S, Knepper A, Beltrame TS. Implicações do conhecimento corporal no comportamento sexual. Rev Bras Educação Física e Esporte. $2009 ; 23(2): 345-54$.

34. Bø K. Pelvic floor muscle training in treatment of female stress urinary incontinence, pelvic organ prolapse and sexual dysfunction. World J Urol. 2012; 30(4):437-43.

Received: 05/08/2013

Recebido: 08/05/2013

Approved: 04/27/2015

Aprovado: 27/04/2015 
